\section{Inhibited Development of Dictyocaulus Larva in the Lungs of Cattle and Sheep}

The limitation to the value of the diagnostic procedure of examining bovine fæces for the larvæ of Dictyocaulus viviparus has become increasingly clear during recent years. It has always been realized that immature worms would not reveal their presence in this way, and more recently the effect of host resistance has been recognized in reducing the rate of egg production by the female worms. A third source of error in attempting to diagnose parasitic bronchitis in cattle by fæcal examinations has now come to our notice, in that we have found Dictyocaulus larvæ invading the lungs of a partially resistant host, to be retarded in their development for some weeks and in some instances for months, and to constitute a possible source of disease that could not be detected by ordinary means even on post-mortem examination.

Having observed the presence of undeveloped Dictyocaulus filaria in the lungs of resistant experimental sheep a hundred days after the administration of infective larvæ, we proceeded to look for the same thing in naturally occurring cases of parasitic bronchitis in adult cattle and, using Baermann's apparatus, we were able to show the presence of minute worms in the lungs of animals that had been showing disease symptoms for some weeks. In one of these cases, the animal had been away from a source of infection for the previous eight weeks. In subsequent experimental infestations in cattle, we have recovered immature worms at post-mortem examination 20 days, 41 days, 56 days and 80 days after the administration of the infective larvæ.

These microscopical worms are in the earliest fifth stage of development, ranging down to $0.58 \mathrm{~mm}$. in length; the largest number that we have recovered in any one instance was 451. On account of the crudeness of the method, however, it seems likely that the actual numbers present were greatly in excess of what we recovered. In most instances, larger worms are also found and sometimes worms of every size throughout the whole range of the fifth stage up to the egg-laying adult.

Helminthologically, the observation is of interest as being an addition to the recorded instances of inhibition of development and extended prepatent period during the parasitic life of nematode worms.

E. L. TAYLOR

J. F. MrOHEL

Veterinary Laboratory,

Ministry of Agriculture and Fisheries,

Weybridge, Surrey. Nov. 19.

\section{Fusarium Wilt of Guava (Psidium guyava L.) in Uttar Pradesh, India}

GUAVA is grown extensively in Uttar Pradesh and is a major fruit crop of the State, occupying nearly 70,000 acres of land. A wilt disease was first reported from the Allahabad district of the State ${ }^{1}$. This district is noted for its fine quality guavas and supplies a very large number of grafted plants from its nurseries to the rest of the country. The disease has advanced with great rapidity within a few years and has become a menace to successful cultivation of this valuable fruit in the eastern districts of the State. A rough estimate puts the area threatened by this disease at about 20,000 square miles.
The symptoms of the disease have been accurately described by Das Gupta and Rai ${ }^{2}$ and Vestal ${ }^{3}$. There has been some difference of opinion about the cause of the disease. The former consider the disease to be caused by Fusarium sp., while the latter attributes it to Cephalosporium sp. In both cases there has been no determination of the species of the causal organism. The present work was undertaken to establish the real identity of the pathogen.

On close examination of freshly wilted plants, we could always find that the surface growth showed the presence of Cephalosporium sp. Very large numbers of isolations from the wilted plants were carried out, and a wide variety of fungi was obtained. The principal among these were Fusarium and Cephalosporium; the latter was distinguished from the former by complete absence of macro-conidia. Besides this major difference, the isolates varied among themselves in the production of pigments, presence and absence of sporodochia and pionnotes and the type of aerial mycelium.

All the isolates so obtained were invariably singlespored, according to the methods of Hansen and Smith $^{4}$. Pathogenicity trials showed that both caused wilting. While producing single spores from pionnotal type, we found that occasionally we got strains which do not form macro-conidia. This type of phenomenon has already been discussed by Snyder and Hansen ${ }^{5}$ and Prasad ${ }^{6}$. We consider that strains showing the characters of Frusarium and Cephalosporium belong to one and the same fungus; but in the case of certain strains the capacity to produce macro-conidia is lost, or we do not know the true conditions under which such strains form macroconidia.

The characters of the strain showing macro-conidia are as follows: sporodochia and pionnotes present, macro-conidia present, mostly 3-4-septate, sickle shaped. Measurements of conidia are: 0-septate, $7-10 \mu \times 2-3 \mu ; \quad 1$-septate, $15-20 \mu \times 3-4 \mu$; 3 septate, $32-40 \mu \times 3-6 \mu$; and 4-septate, 37-50 $\mu \times$ 4-7 $\mu$. Chlamydospores present, both intercalary and terminal.

These characters place the organism under section Elegans of Wollenweber and Reinking's system of classification. Snyder and Hansen ${ }^{5}$ have shown the unreliability of the characters separating the species in this section, and have reduced the entire section to one species, namely, Fusarium oxysporum Schl. emend. Snyd. et Hans. We accept Snyder and Hansen's concept of species in the genus Fusarium, and propose to name the guava wilt pathogen Fusarium oxysporum f. psidii.

\section{Agricultural Institute,} Anand.

\section{N. Prasad}

P. R. MEHTA

S. B. LAL

Laboratory of the Plant Pathologist, Government of Uttar Pradesh,

Kanpur.

Nov. 27. 'Hayes, W. B., "Fruit Growing in India" (Kitabistan. Allahabad,
1945).

2 Das Gupta, S. N., and Kai, J. N., Curr. Sci., 16. (8), 256 (1847).

${ }^{3}$ Vestal, E. F., "Text-book of Plant Pathology", 496 (Kitabistan, Allahabad," 1950).

'Hansen, H. N., and Smith, R. E., Phytopath., 22, 953 (1932).

${ }^{5}$ Snyder, W. C., and Hansen, H. N., Amer. J. Bot., 27, 64 (1940).

- Prasad, N., Phytopath., 39, 133 (1949). 7 Wollenweber, H. W., and Reinking, O. A., "Die Fusarien". (Paul
Parey, Berlin, 1935). 